\title{
Relationship between Literature and Life
}

\author{
Nila Akhter Khan
}

${ }^{1}$ Lecturer, Department of English, Gono Bishobidyaloy, Bangladesh

DOI: $10.36347 /$ sjahss.2021.v09i03.002

| Received: 14.02.2021 | Accepted: 16.03.2021 | Published: 20.03.2021

*Corresponding author: Nila Akhter Khan

Copyright (C) 2021 The Author(s): This is an open-access article distributed under the terms of the Creative Commons Attribution 4.0 International License (CC BY-NC 4.0) which permits unrestricted use, distribution, and reproduction in any medium for non-commercial use provided the original author and source are credited.

Literature is the likeness of the life in all its varied forms and shapes. Literature is reflecting of the society. It depend ahead the writer where he places the mirror. From time to time writers have been exploring the variety of dimensions of the relationship between man and society. Every era has its own compulsions, tensions, fear aspirations and logic which characterize the work of that time. Novel emerges as a powerful intermediate to present the age in a descriptive and analytical manner. It represents the social, political, cultural and historical growth of society at a greater length. History and Literature are intimately associated with each other. Literature must not be perplexed with sociology, philosophy, religion or psychology, though these give substance and depth to literature. It may or may not communicate knowledge or religious or moral instruction directly. Its theme may be social trouble or political revolution or religious movement; but it may, with equivalent justification, be an individual's passion, problem or fantasy. But the entity is not so much to teach as to delight. Books are literature when they bring us into some relative with real life. Herein lays the power and universal appeal. While there are some who take excellence of form to be the chief pre-occupation of literature, many more are inclined to the view that the primary value of literature is its human implication. Literature must be rush out of the stuff of life as its mirror. Its worth depends on the depth and breadth of the life that it paints. In modern era, our notion of the depth of literature is not related the doctrine of undying truths. We try rather to understand the forces after the social changes. Therefore with regard to literature, our ideas of its value depend on the extent to which it has been able to communicate the changing conditions of social life. Great literature forever grasps and reflects these truths of life that emerge triumphant out of the ruins of the past.
Literature is enormous because of its universality. It does not deal with the particular society of a scrupulous community but with society as a whole or in its entirety. For this cause, the literature that appealed to the people through the spoken word had a greater appeal than that which appeals through the written word - which may not reach all men. The recited epics of Homer, the acted plays of Shakespeare, the chanted songs of Chandidas or the communal reading of MangalaKavya had a more extended appeal than our current poets and novelists who articulate only segments of social life. Poetry that expresses intensely individual views and sentiments; novels that depict the manner of limited class of community or deal with highly specialized problems, cannot surely be of the same level as are Tulsidas's Ramcharitmanas which had and still have a mass appeal. This lead Aristotle to asserted that the proper subject of poetry is human action. Literature is the phrase of individual and social life and thought through language. While the subject material and treatment must be such as are of universal human interest, the expression must be emotive; the form must give aesthetic pleasure and satisfaction. Literature must liberate mind from its confines; arouse it to a consciousness of the dynamic advise of life.

The study of English Literature allows people to expand novel ideas and new means of thinking about the world. In literature, we find stories intended to portray human life and action through a few characters who, by their words, action and reaction, communicate convinced messages for the purpose of education, information and entertainment. It is impracticable to find a work of literature that get rid of the approaches, morale and values of the life, as no writer has been brought up entirely unexposed to the world around him. What writers of literature do is to communicate the reallife measures of life into fiction and present it to the people as a mirror with which people can look at 
themselves and make compensation where necessary. It is capable of bringing about different emotions and a general sense of "spiritual" well-being.

The mission to find out a definition for "Literature" is a street that is much travelled though the point of influx if ever reached is rarely satisfactory. Most attempted definitions are wide and indistinct, and they inevitably alter over time. In fact, the only thing that is convinced about defining literature is that the definition will change. Concepts of what is literature alter over time as well. What may be considered normal and not laudable of remark in one time period may be considered legendary genius in another. Early on reviews of Emiley Bronte's Wuthering Heights in 1847 were less inspiring; however, Wuthering is at the present considered one of the greatest literary achievements of all time. The similar can be said for Herman Melville's Moby-Dick 1851.

A literary man is as a great deal a product of his society as his art is product of his own response to life. Even the greatest of artist is sometimes as conscious, sometimes an unconscious advocate of his time-spirit. The time-spirit is the total outcome, the quintessential accumulation of all the political, social, religious and scientific changes of a particular age. The historical feature of literature, therefore, minor or inconsequential though it may be for aesthetic purpose, cannot be totally ignored. Thus literature imitates his zeitgeist or the time-spirit. No writer can run gone influence of his age. Literature always expresses the thoughts and emotion of human mind which are closely connected with and conditioned by the age. The influence of the age on the human mind is due to the fact that the latter is constantly influenced by the spirit of the age and reacts to it intensely and vigorously.

The indication of the age depends on the excellence of the mind in which it is reflected. If a work of literature is to be adjudicated by the quality of this reflection, it is obvious that it depends on the quality and nature of the reflecting mind. Literature means something that is written for refreshing and inspiring the mind. It records the thoughts and feelings of great minds. It attracts in two traditions - through its matter and through its way. The matter must be such that those who interpret it are interested in some way. The way must be such as will be pleasing to the reader and adds to his fund of knowledge.

As per thought of the Shelly poets the unacknowledged legislator of mankind. The functions of a legislator are to put down down the law, a settled course of action that men may follow. Poetry and literature generally do this in a quiet and unobtrusive way. Novels are acknowledged to have changed the direction of the human mind and set in motion movements that have changed our ways of life. The influence of literature on life is felt directly or indirectly.

Thus Miss Stowe's “Uncle Tom's Cabin” was directly accountable for a movement against slavery in literature and life in USA of those days. The novels of Dickens had an indirect influence in creating in society a feeling for regulating and removing social wrongs, calling for essential reforms. It is, thus, obvious that if we are concerned in literature and its persuade is bound to shift us amply.

Literature is made out of wisdom of life. No hesitation, the realistic artist brings to a hub the oddities and cruder characteristic of life overmuch. But to recognize life fully, not only the bright side but also the seamy and dark elevation of life is to be recognized. Thus, society makes literature. It may be explain as the mirror of the society. But the quality and nature of the reflection depends upon the writer's approach of mind, whether he is progressive in his viewpoint or reactionary.

It is an admitted fact that if the work of a writer simply reflects the spirit of his era, it cannot be a great literature. It is a very helpful piece of precious material for the sociologist and the historian. It is completely devoid of the virtue of permanence and ubiquitous. The literature of the Greeks may not petition to a Bangladeshi or a German mind if its historical factor is taken into consideration. Similarly, Shakespeare may not be considered a great dramatist, if he simply and purely imitated the Elizabethan period.

The aroma of literature lies in the individual move toward of the author, his personality which will govern over other influences. Undoubtedly, the author is wrought by the spirit of his age, but he has also got the capabilities to mould his period. A great man of letters is the creature as well as creator of the era in which he exists. Therefore, we talk of the age of Shakespeare, the age of Dryden, the age of Pope, the age of Wordsworth, the age of Bernard Shaw and so on. For example, Milton's Paradise Lost, was a great confront to the age of cynicism, low morals and satirical literature. This potent book does not reveal the timespirit of his age. Milton revolted rather than expressed the spirit of his times. Similarly, in spite of all the atmosphere of heroism, noble ideas and love of song and drama, the Elizabethan age could not create another Shakespeare. The purpose of literature is diverse from that of history. Literature is revelation of beauty. Beauty is the expression of sentiment and all such expression without several exceptions is beautiful.

Literature as a entire grows and changes from generation to generation. It is not stationary but dynamic. It means that each age has its own fastidious point of interest and its own particular way of thinking and feeling about things. So the literature which it 
produces is governed by certain prevailing tastes. These taste previous for a time only. The taste of one age is sure to differ and often is found to differ extremely from those of another. We all know that there was no public to enjoy the identical kind of poetry in Pope's day as in Spenser's, or in Scott's day as in Pope's. In Spenser's day there was boundless enthusiasm for The FarerieQueene; in Pope's for the Essays of Man; in Scott's for the Lady of the Lake.

Thus for pattern, one of the key forces behind the English Literature of the Elizabethan era was the enormous enthusiasm for the Greek and Latin classics which had come with what we call the Renaissance. Our writers and readers comparable were under the powerful spell of Italian literature during the same period, under that of French literature at the end of $17^{\text {th }}$ century, under that of German literature a hundred years later. The Reformation, Puritanism, the French Revolution, the enormous advancement of science during the $19^{\text {th }}$ century, it is enough to mention these to show the close association between the story of literature and history.

Literature has a national as well as a personal character and curiosity. Literature can be observed from age to age and it's various transformations. It is not only an account of work done by a numeral of separate writers, but it is also an account of great body of literature which in its totality is to be regarded as the making of the intelligence of the people. Everything that for good or sin has entered into the making of our nation's life has also entered into the feel of literature. Normal English history is English nation's biography and its literature is its autobiography. As we review the history of English literature through all its transformations, we are brought into direct and living contact with the motive forces of internal life of each consecutive generation and learn at first-hand how it viewed at life and what it thought about it, what were the belongings in which it was most interested and by which it was most willing to be amused, by what passions it was most deeply stirred, by what standards of conduct and of taste it was governed, and what types of character it deemed most worthy of its admiration. Thus, literature is the exposure of the progressive mind as well as the spirit of the people.

The French Revolution brought to Europe the hope of political freedom and social renovation. Though the anticipated was dashed to the ground with the accession to power of Napolean, its place was taken by the eagerness of the struggle of the nations against old regimes. Wordsworth was extremely saturated with the dogmas of the French Revolution. The Prelude analyses as well as communicates the progress of Wordsworth's political sympathies. The French Revolution stirred in him republican sympathies which were strengthened by his visit to France. Wordsworth records the outlook of those days:

\section{Bliss was it in those days to be alive,} But to be young was very heaven.

Wordsworth and Coleridge were close friends. Coleridge like Wordsworth went through a phase of innovatory ardor. All his poetical characters were deeply precious by his age. The French Revolution disillusioned him and he diverted his attention to spiritual idealism which provided him mental contentment. Although Byron did not express the French Revolution in his works, yet he downs the revolutionary spirit in its action alongside old social conventions. He simply inherited the revolutionary aspirations which were cherished by Wordsworth and Coleridge and then afterward on rejected by them because of the violence of the Region of Terror. Byron excelled most other poets of England in his being one of the supreme poets of revolution and liberty. Shelly also became the most melodic singer of the Revolution and the poet of the revolutionary idealism. He probed into the springs of Godwinion philosophy. He was fundamentally the poet of the Future. His passionate love of liberty, his loathing for intolerance, his impatience of control for self and others, his vivid logical sincerity, combined to make him the Quixotic champion of tremendous opinions.

There is a close linked between literature and life. It is, in fact, life which is the subject matter of literature. Life offers the raw material on which literature imposes an artistic form. Literature is the communiqué of the writer's experience of life. But this connection between literature and life is not as simple as it seems. This difficulty has been discussed by some of the maximum literary critics of the world, and their conclusions have been sometimes contradictory.Plato, the great Greek philosopher, was the first to give a solemn thought to this problem - the relation of literature and life. In his discussions he referred chiefly to poetry but what he said about poetry can be uniformly applied to literature as a whole. He regarded poetry as a mere "imitation" of life, and thus he fated the poets. His antagonism to poetry was based on his hypothesis of knowledge. According to him, true realism consists in the ideas of things, of which individual objects are but reflections or imitations. There is an obvious error in Plato's logic. Being too much of a philosopher and moralist, he could not see evidently the relation between literature and life. He is right when he says that the poet produces incredible which is less than reality it purports to symbolize, but he does not perceive that the writer also creates something more than reality. This fault as corrected by Plato's scholar, Aristotle. In Poetics he undertook to inspect the nature and qualities of creative literature with a view to representing that it is true and not false as Plato had shown it. He approved with Plato that poetry is an imitation of reality, but according to him, 
this imitation is the intention representation of life in literature or in other words, the imaginative modernization of life. Poetry is thus not linked with the outside world in the simple and direct fashion supposed by Plato. The poet first gets an inspiration from the world by the supremacy of his imagination; the art of poetry then imitates this imaginative inspiration in language. The poet is anxious with the truth - but not the truth of the annalist, the historian or the photographer. The poet's trade is not to write of events that have happened, but of what may happen, of things that are possible in the light of probability or necessity. For this rationale poetry is more philosophical, a more serious thing than history. For whitest history treaty with the particular only - this event or that event, poetry deals with the worldwide. Sir Philip Sydney, who next took up the question of the relation of literature to life, also refuted Plato's contention that literature is a measly imitation of an imitation. As per his viewed, the poet does not imitate, but he creates; it is the reader who imitates what the poet creates. Taking his material from the real world, the poet creates an ideal world by means of his imagination. For Sidney the ideal world of the poet is of value because it is a better world than the genuine world and it is obtainable in such a way that the reader is stimulated to try and imitate it in his own perform. The problem of literature's relation to life was next taken up by Dryden who keen out that imaginative literature gives us a "just and lively" image of human nature by representing its "passions and humours". This point was auxiliary developed by Dr. Johnson who expressed the view that the poet "holds up a echo to nature". According to him, "Nothing can please many, and please long, but just representation of general nature." According to Dr. Johnson, the poet must know the manners and customs of men of all times and conditions, not because it is his duty to make glowing to the reader the diverse ways in which men have lived and behaved, but so that he is not taken in by surface differences and is able to enter to the common humanity fundamental there. According to Walter Pater, a critic of the later $19^{\text {th }}$ century, who discussed the relation of literature and life in detail, the literary artist does not give us a photographic 'imitation' of reality, but a transcription of his dream of it. It is from reality or life from which the artist starts, but he tries to renovate it when he would "see it steadily and see it whole."

Taking into contemplation the views of Plato, Aristotle, Sidney, Dryden, Johnson and Pater, we conclude that the idea that literature is not concerned with real life is wrong. All immense pieces of literature are "true to life". But the legendary artist is not content to 'hold the mirror uptown the nature', because his business, as Mathew Arnold has pointed out, is a "criticism of life". He concentrates on those uniqueness and aspects of life which are enduring, but which might easily pass unobserved. He clutches at anything which assured some permanence among what is always fleeting. That is why he gives us a picture of realism which is more characteristic of life than anything which we discover by our own day-to-day observation. The images which we are creating by our own surveillance of life at every moment of our working experience are hazy, half-finished and unrelated. It is the literary artist who finishes them, makes them clear and puts them in their wider setting, and to that extent makes life less obscure, because he knows more about life than anyone can know without regarding life with his eyes.

\section{"Works Cited"}

1. Pope, Alexander. "The Rape of the Lock"

2. Muller, J. H. Is Art the product of its Age?

3. Emile, Legouis, A History of English Literature: Oxford, 1934.

4. Nayar K. Pramod, A History of English Literature: New Delhi, 2009.

5. KingslayDevis, Human Society ( New York Macmillan Co., 1949) p. 392

6. Trans by C. H. Tawney, Thacker Spink and Co., Calcutta, 1891, p. 03.
} 